\title{
STRUCTURAL ELEMENTS OF CONSTRUCTION OF INDIVIDUAL AND GROUP EXERCISES COMPETITION COMPOSITIONS IN CALISTHENICS
}

\author{
Kovalenko Y.O., Boloban V.N.
}

National University of Physical Education and Sport of Ukraine

\begin{abstract}
Purpose: to analyze content of individual and group exercises' competition compositions in calisthenics. Material: in the research HEEs' girl students $(n=20)$, junior sportswomen $(n=10)$, experts $(n=30)$, coaches with 10-40 years' working experience participated. Results: it was found that temporary indicators permit to assess level of female gymnasts' readiness for fulfillment of competition compositions' elements; facilitated rational correlation of body and object's elements of complexity. Quickness of preparation to elements and directly time of exercise's fulfillment acquire great importance. In individual and group exercises the most important are distribution of sportswoman's moving on all site with frequent change of directions. It was established that realization of structural elements facilitates full opening of female gymnast's artistic image. Conclusions: for building of competition compositions coaches shall fully use indicators of space and time structural elements.
\end{abstract}

Key words: female gymnast, composition, subject, building, coordination, space, time.

\section{Introduction}

Ukrainian female gymnasts have high sports achievements in the world. However, sports rivalry grows and new problems appear. Leading specialists connect these problems with building and demonstration of spectacular competition compositions [3, 5, 7, 12, and 14]. In modern calisthenics high requirements are set to competition compositions of sportswomen (Code FIG, 2013-2016). Female gymnasts shall fulfill complex elements at high technical level and their movements shall be graceful, plastic and artistic. The highest sports achievements in calisthenics imply artistic execution of composition under musical accompaniment with maximal demonstration of coordination abilities, flexibility, jumping, balance, and vestibular stability, consummate manipulation of object [3, 11, and 19].

During recent three Olympic cycles (2004-2016) a tendency of systematic increase of individual and group exercises' competition compositions complexity in calisthenics has being existed. Competition is constantly rising on world gymnastic platform. It is more and more difficult to win a victory. Only those female gymnasts, who will demonstrate artistry of competition programs' fulfillment against the background of perfect body control and object's manipulation, will be leaders. The problem of individual approach to training of sportswomen's motor abilities, basic technical fitness in formation of personality features. Solution of this problem is possible by building of competition compositions, by opening of female gymnasts' artistic and emotional skillfulness [6, 12]. In competition rules in many kinds of sports with complex motor coordination there are no clearly differentiated criteria of exercise spectacular level, sportswoman's artistry, technique's originality, complexity and sequence of exercise' fulfillment assessment. In many works it is noted that success of individual exercises' compositions in calisthenics (sports gymnastic, sports acrobatic) depends on skillful combining of all components in one as well as obeying of music's emotional content to this one $[7,10,11]$.

There are rather few researches of methodic of competition compositions' building, considering FIG requirements. With the help of this document control over development of calisthenics in the world is realized (Code FIG, 2013-2016). In particular, new requirements have been set to space-time characteristics of exercises and combinations of exercises [19].

Purpose, tasks, material and methods of the research

The purpose of the research is to analyze content of individual and group exercises' competition compositions in calisthenics.

The tasks of he research:

1. To study theoretical-methodic status of the problem of competition compositions' building in individual and group exercises' of calisthenics.

2. To analyze space-time structural elements of individual exercises competition compositions' building for elite female gymnasts.

(C) Kovalenko Y.O., Boloban V.N., 2015

doi:10.15561/20755279.2015.0602 
The methods of the research: for solution of the set tasks we used the following methods: analysis and generalization of scientific-methodic literature data; questioning; video-computer analysis of female gymnasts' exercises; analysis of competition records; methods of mathematical statistics.

\section{Results of the research}

For studying of competition compositions of girl students' individual exercises we fulfilled questioning. Analysis of data permitted to calculate time for composing and further correction of competition compositions [4]. Most of coaches (43\%) answered in the following way: they spend 1 day for composing; $40 \%$ of coaches answered - 5-6 days and $17 \%-$ 2-3 days (see fig. 1). Coaches' opinions differed in question of competition compositions' correction: $13 \%$ of specialists' correct compositions during 1 day; 37\% - during 5-6 days; $23 \%$ - during 3-4 weeks; $17 \%$ - during 2-3 months. Only $10 \%$ of coaches change competition programs during year. Coaches, who correct compositions during 1 day, base on their inspiration. In the future they correct programs and change them for perfection of exercises' elements.

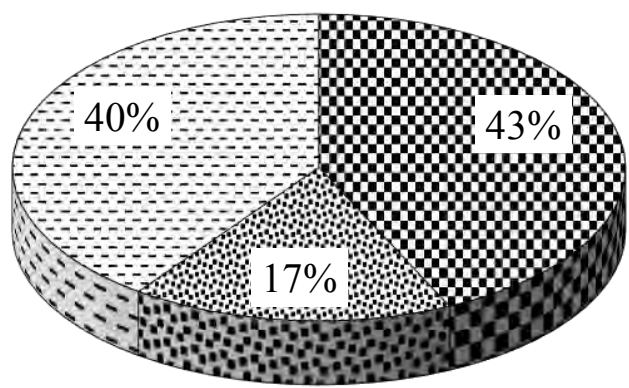

Fig.1. Percentage of correlation of time (days), spent by coaches for composing of competition compositions of individual exercises.

1day

2-3days

- 5-6 days

Questioning of coaches permitted to determine sequence of work on creation of artistic image of competition composition. At $1^{\text {st }}$ place there is expressiveness of sportswoman, at $2^{\text {nd }}$ - working out of new elements and their connections (in compliance with music); at $3^{\text {rd }}$ place -watching video-records of competition compositions of the strongest in the world female gymnasts; $4^{\text {th }}$ place - visiting of world competitions or international elite competitions; $5^{\text {th }}$ - working out of leotard style; $6^{\text {th }}$ - watching film (if musical accompaniment is soundtrack of film); $7^{\text {th }}$ place - choosing of color gamma of object. In analysis of female gymnasts' answers to this question we found many similarities with coaches' answers. The only distinction is that female gymnasts put on the $1^{\text {st }}$ place working out of new elements and their connections (in compliance with music) and on the $2^{\text {nd }}$ place - expressiveness of female gymnasts.

Among the questioned respondents $93 \%$ said that they train female gymnasts' ability to compose compositions. It is a positive feature for development of female gymnasts' creative potential.

Competition rules dictate the following requirements: in competition composition it is necessary to demonstrate complexity of body movements (D); combination of dance steps, dynamic elements with rotation or throws of object, skillfulness in manipulation of object. Female gymnasts' motor actions shall be fulfilled in strict space-time frames, which are accessible for perception of spectators and assessment of referees.

For this purpose we analyzed competition compositions of female gymnasts.

In process of video-analysis we considered the following components:

1. Time, spent for fulfillment of body movements' complexity (D1).

2. Time, spent for fulfillment of object's complexity (D2).

3. Time, spent for fulfillment of risky elements (R).

4. Kinds of movements and covered distance in meters in competition composition.

In exercise with hoop we found the longest time, spent for fulfillment of body movements' complexity in Ukrainian and Byelorussian female gymnasts $\left(35^{\prime \prime}\right)$. With it the shortest time was demonstrated by Russian female gymnast (23.01"). It was conditioned by the fact that Russian female gymnast fulfilled minimum of possible elements (7). It did not reflect in total sum of points for body movements' complexity. Female gymnast from Byelorussia shortened time for work with object by $6^{\prime \prime} 2^{\text {nd }}$ stage of research. Female gymnast from Azerbaijan increased time indicators of body 
movements' complexity by $18^{\prime \prime}$. It permitted for sportswoman to show all skillfulness in handling object at the account of shortening of time spent for body work and dynamic elements with throws (see table 1).

Table 1. Comparative analysis of time indicators of time spent for fulfillment of body movements' complexity, object's complexity, dynamic elements in exercise with hoop $(n=10)$

\begin{tabular}{lllllll}
\hline $\begin{array}{l}\text { Countries- } \\
\text { participants }\end{array}$ & $\begin{array}{l}\text { Body } \\
\text { complexity }\end{array}$ & movements' & \multicolumn{2}{l}{ Object's complexity } & \multicolumn{2}{c}{ Dynamic elements } \\
& I & II & I & II & I & II \\
\hline Azerbaijan & 33 & 26.03 & 32.6 & 50.1 & 24.4 & 15.03 \\
Bulgaria & 20.99 & 28.03 & 52.01 & 43.01 & 15 & 17.12 \\
Byelorussia & 27.5 & 35.1 & 51.3 & 39.21 & 11.2 & 13.2 \\
Russian federation & 28.26 & 23.01 & 49 & 44.06 & 12.84 & 16.3 \\
Ukraine & 42.4 & 35.05 & 29.6 & 39.1 & 15 & 16.07 \\
\hline
\end{tabular}

$1^{\text {st }}$ stage - performance of female gymnasts as per junior program at European championship 2012, Nizhny Novgorod $2^{\text {nd }}$ stage - performance of female gymnasts by senior program (16 years and older) at World Championship, 2013, Kiev.

Analyzing space indicators of female gymnasts' movements in competition compositions on platform we researched types and kinds of sportswomen's movements on every composition.

For female gymnasts from Byelorussia and Ukraine semi-circumferential movements were characteristic. It widens possibilities of movements and opens all harmony of movements. Female gymnast from Russian Federation preferred multiple diagonal movements. It also witnesses about rational composition of jump and dynamic elements with throws. Female gymnast from Azerbaijan increased her distance indicator by 20 meters. She approached her result to leader's result in this parameter - female gymnast from Russian Federation (who covers 75 meters). The least distance was passed by Ukrainian female gymnast (45 meters). Most of composition she was in static positions and fixed elements of body movements' complexity. It is not a negative factor in technique of performance. When fulfilling several elements of body movements' complexity at the spot female gymnast loses opportunity to watch all range of movement (see fig.2).

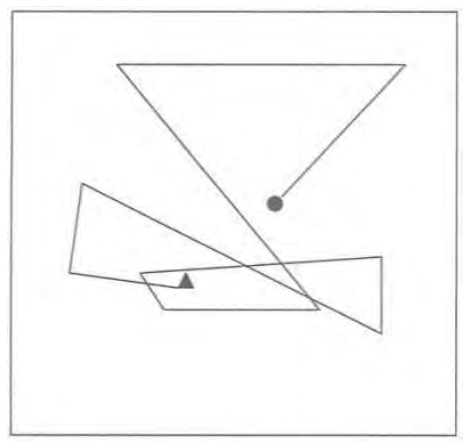

a

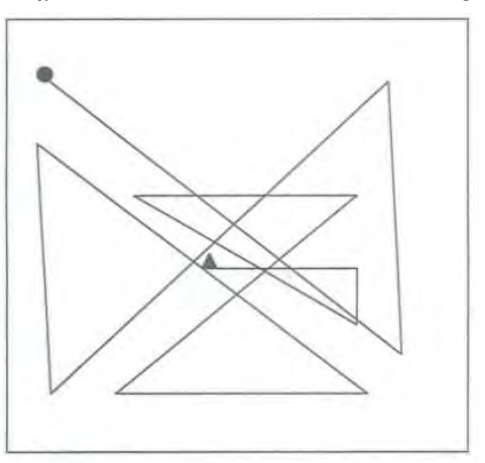

d

b
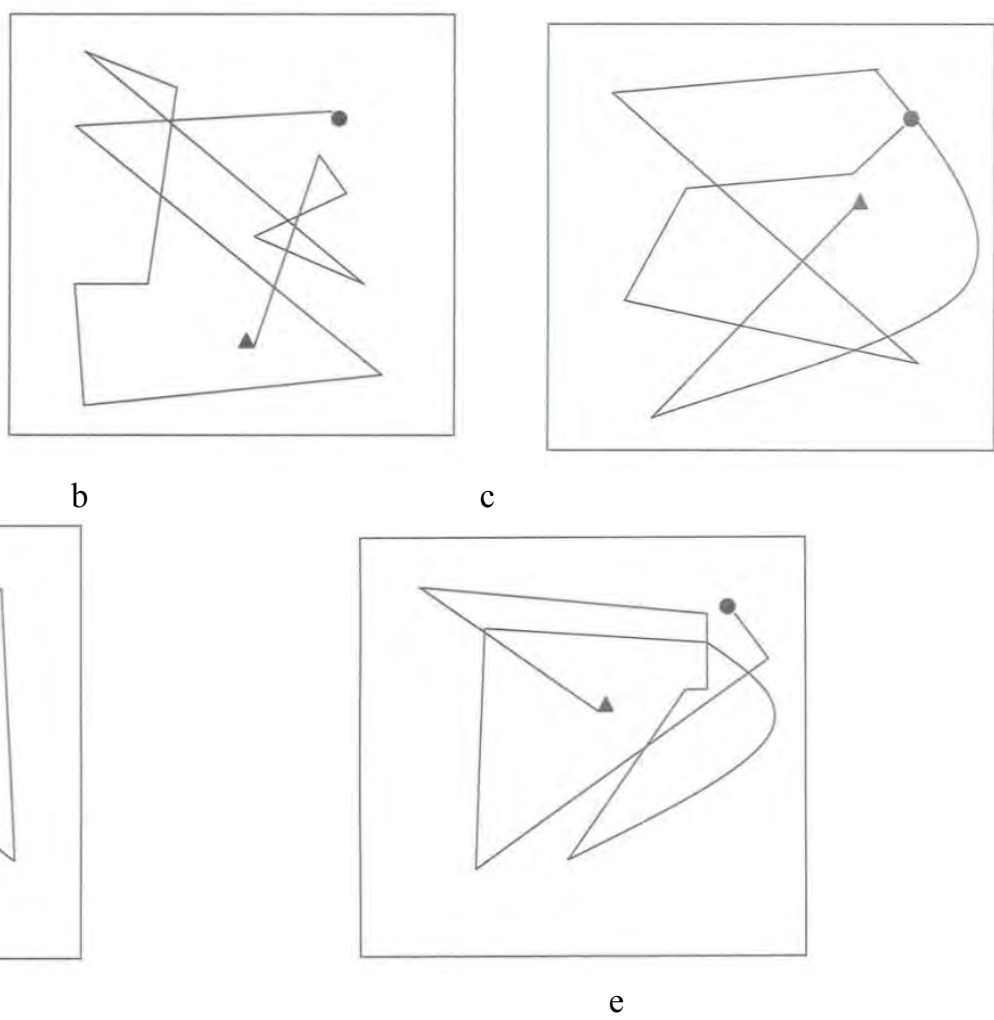
Fig.2. Kinds of female gymnasts' movements on platform in competition compositions with hoop:

a - composition with hoop of female gymnast from Azerbaijan;

$\mathrm{b}$-Composition with hoop of female gymnast from Bulgaria;

c - Composition with hoop of female gymnast from Byelorussia;

d-Composition with hoop of female gymnast from Russian Federation;

e - Composition with hoop of female gymnast from Ukraine;

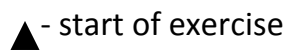

- end of exercise

For studying of competition compositions we carried out video-analysis of performances of 10 strongest teams from 5 countries in group exercises: Spain, Italy, Byelorussia, Russian Federation and Ukraine.

The purpose of video-analysis was to study space-time indicators of group exercises' competition compositions building $(\mathrm{n}=10)$. In analysis we considered the following components:

1. Time, spent for fulfillment of body movements' complexity, throws, combinations of dance steps (D).

2. Time, spent for cooperation of female gymnasts $(C)$.

3. Time, spent for fulfillment of risky elements (R).

4. Kinds of female gymnasts' positions at throws.

Analyzing video-records of group exercises' compositions of strongest teams (World Championship 2014) we studied duration of compositions. In average it was $2.30 \pm 0.03$ ". With it there were registered no rough violations of rules. In group exercises with 10 clubs we found that all teams started their compositions with cooperation elements. It coordinated interaction of female gymnasts and increase spectacular character of performance. Elements of cooperation take in average 70-76". Team from Byelorussia spent 79". The team showed the highest quantity of interactions with the help of supports, multiple exchanges of objects, female gymnasts' passing under objects. Sportswomen used criteria of increasing of cooperation value: without visual control, without hands. In average fulfillment of risky elements by teams took 4-5". Exclusion was team from Spain. This team spent 11" for risky elements. It was conditioned by the fact that sportswomen fulfilled combination of elements turn by turn. It added dynamism to exercise and space movement of all female gymnasts during risky element's fulfillment. For elements of body movements' complexity gymnasts spend in average 50-70". In exercise 10 complexities shall be presented: 5 with exchange of object and 5 without exchange [19]. The most wide-spread element of body movements' complexity ("fouette") was fulfilled by all teams. In average sportswomen fulfilled 6-8 rotations (it took 6-8"). Rotation "fouette", with its synchronous fulfillment, makes exercise effective and spectacular. Among jumping elements the most wide-spread is "jete anturnan". This jump permits to overcome big distance in movement and takes in average 2-3". Team from Byelorussia fulfilled series of jumps, consisting of two "jete anturnan" (time - $3^{\prime \prime}$ ). That is why in exercise of Byelorussian team more time was spent to interaction and cooperation. In Spain team 6" were registered, which was not in any way marked in card of fulfillment of complexities and did not result in any points for fulfillment. Female gymnasts rhythmically moved with object but they did not interact. Probably it was purposeful to add 2" for fulfillment of dance track, which, according to competition rules, shall take 8 ". It would permit to receive 0 . Points (see fig. 3).

We regarded female gymnasts' positions (orders) on platform during throws in group exercises with 10 clubs. In Ukrainian female gymnasts 2 throws one-by-one were registered. Pictures of throws were different. First throw was fulfilled with moving forward. It permitted for sportswomen to prepare for second throw, which was fulfilled in static position (see fig. 4).

Italian and Spanish sportswomen demonstrated similar types of positions for throws. They included: diagonal, vertical, horizontal, cross-like orders and circles. Byelorussian team did not demonstrate variety of throw orders. Three kinds of positions were noticed. With it, two throws were fulfilled consequently. Also position of throw start was changed in second throw. Female gymnasts started throw from initial position "on the floor". All throws of Byelorussian team were fulfilled at high speed, spontaneously with elements before and after throw of object. It visually increased effectiveness and complexity of competition composition. 


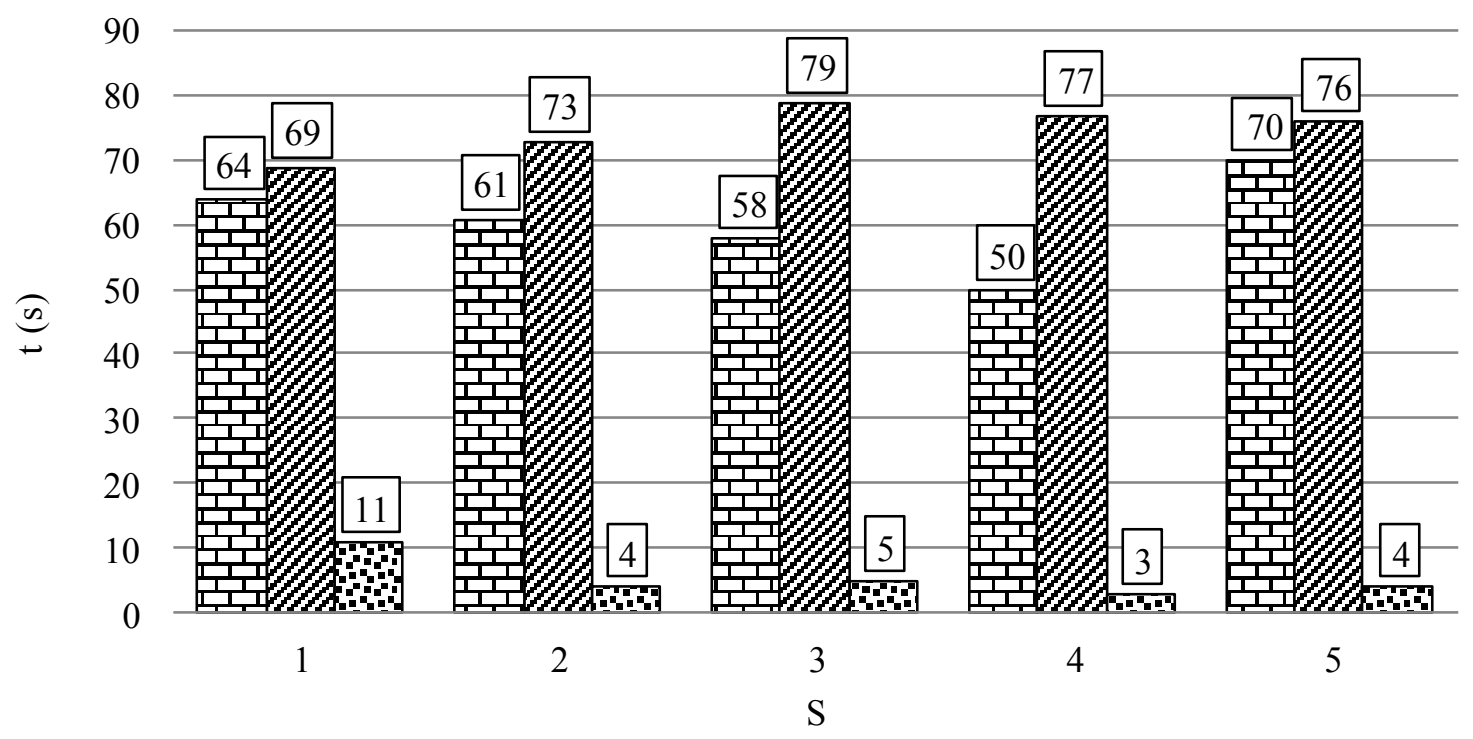

Fig.3. Indicators of time, spent for fulfillment of body movements' complexity elements (D), cooperation elements (C), risky elements $(\mathrm{R})$, in group exercise with 10 clubs: $\mathrm{t}$ - time in seconds; $\mathrm{S}$ - team of country; 1 -Spain, 2 -Italy, 3 Byelorussia, 4 - Russian Federation, 5 - Ukraine.

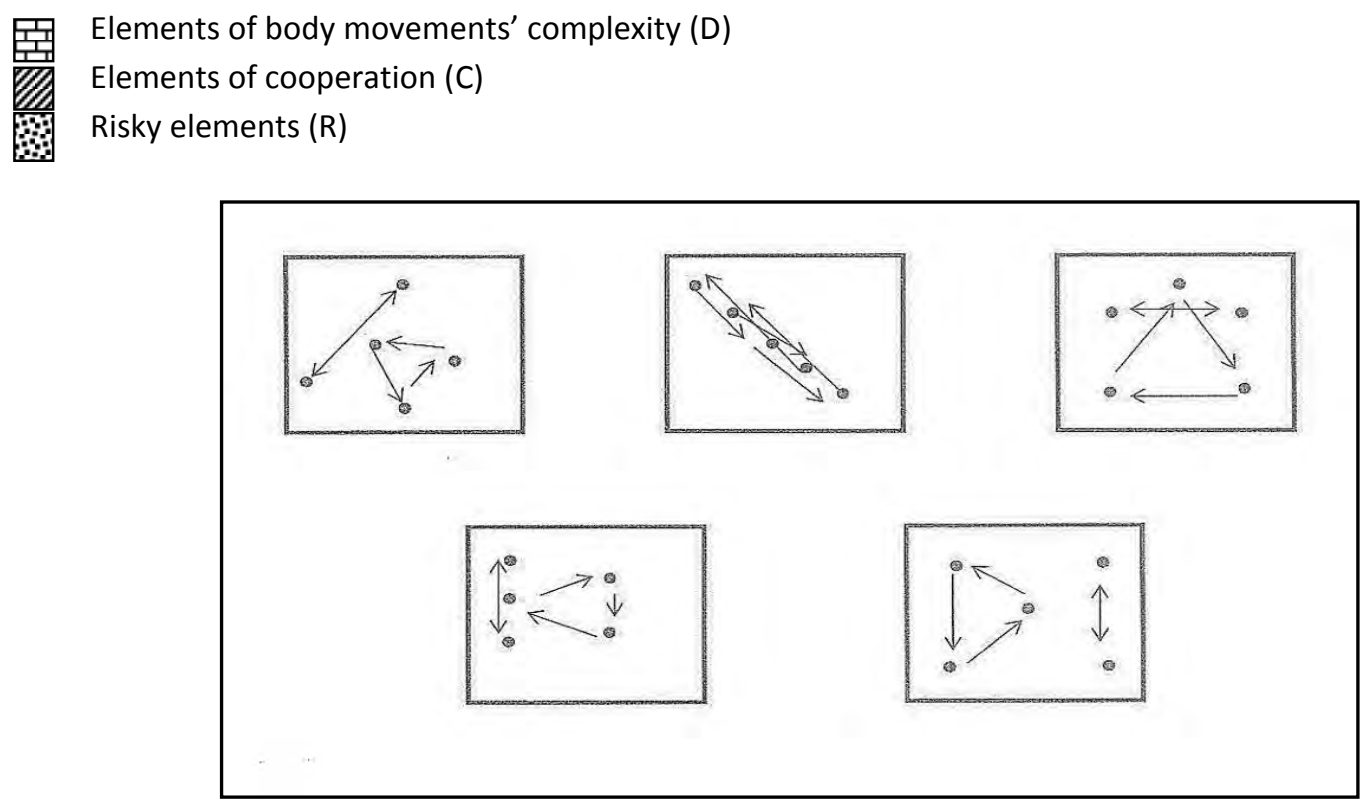




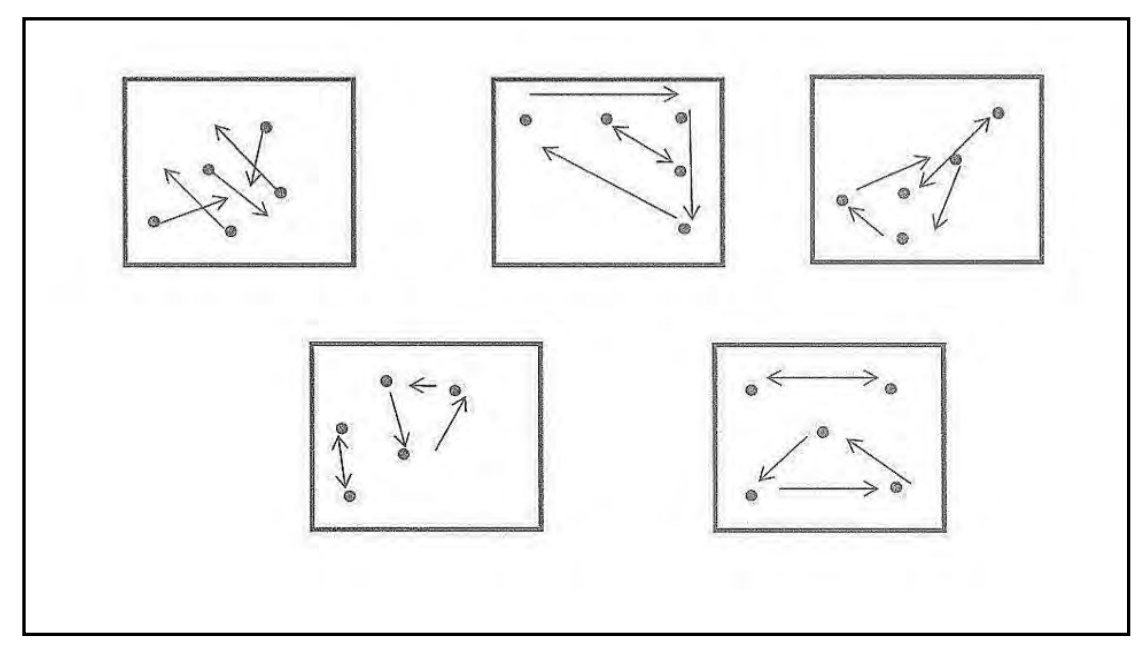

2

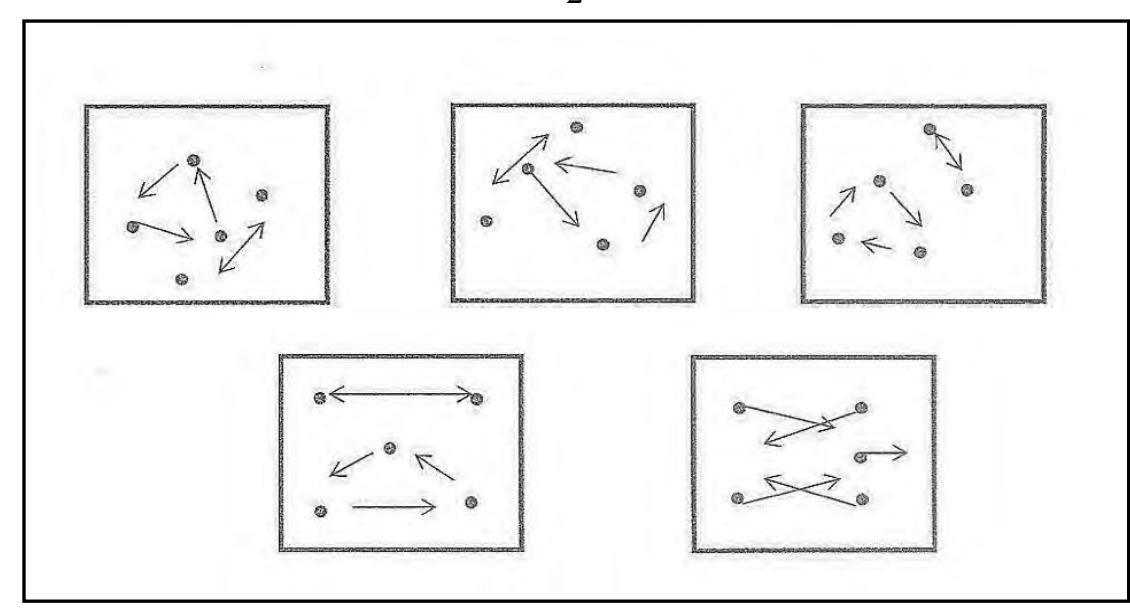

3

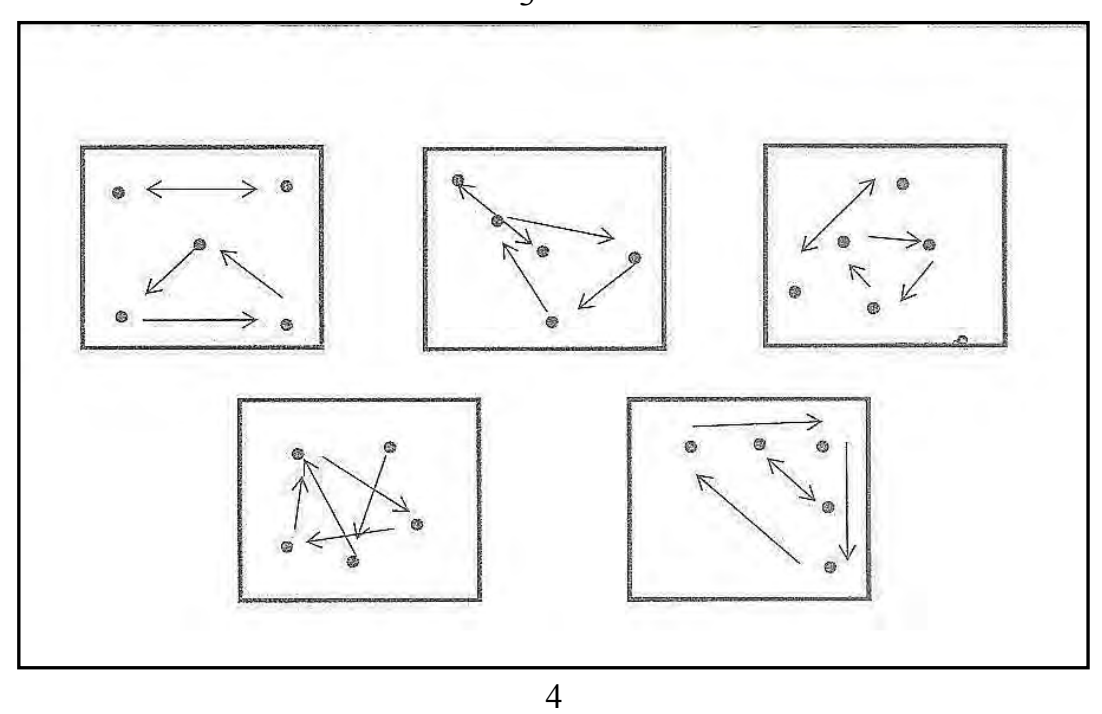




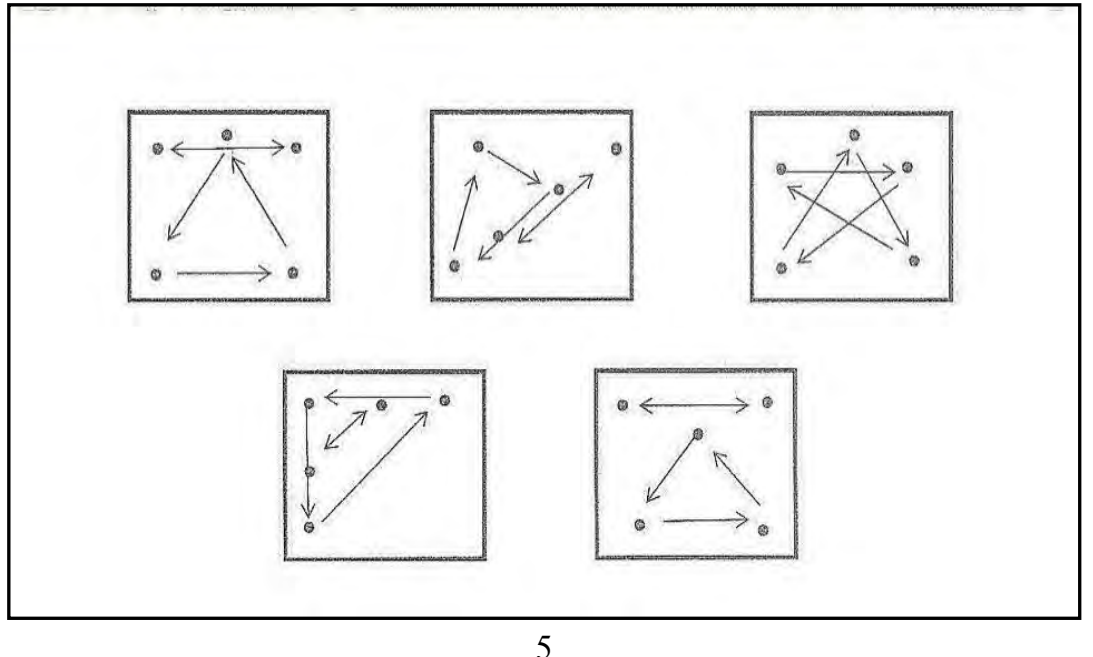

Fig. 4. Positions of female gymnasts (orders) on platform during throws in group exercises with 10 clubs in teams from: 1 -Spain; 2 - Italy; 3 - Byelorussia; 4 - Russian Federation; 5 - Ukraine.

\section{Discussion}

"Composition" implies composing of one from parts; building of artwork, conditioned by its content, character and purpose. In competition rules on calisthenics (principle document of International federation of gymnastics) high requirements to competition compositions of individual and group exercises are presented. New requirements to demonstration of space-time indicators in fulfillment of separate elements, their combinations, composition in the whole are set. These requirements concern: dynamic wholeness of exercises' phases; frequent change of movements' directions; rational distribution of elements in individual and group exercises (when moving by diagonal, by circle, by arch); distance, covered by female gymnast in composition; stability. Our researches showed that distance, covered by gymnast is the socalled indicators of female gymnasts' sportsmanship. For Ukrainian and Byelorussian female gymnasts, in compositions with hoop accentuated moving by circle were characteristic. It permits to move on platform and open technical potentials. In one composition gymnasts cover up to 45 meters. Female gymnast from Russian Federation covered twice bigger distance in exercise with hoop - 75 meters. In exercises with hoop sportswomen successfully add wide-amplitude movements by body and elements of complexity. It is an indicator of high sportsmanship, which was confirmed by high referees' marks. For example, gymnast Ya. K. Won title of absolute World Champion in calisthenics for 2013. Analysis of structural elements of group exercises' competition compositions shows complex constructions, functional cooperation and systemic motor interactions of gymnasts in exercise with 10 clubs. Video-analysis helped to study: time of fulfillment of complexity elements; combinations of dance steps; cooperation; fulfillment of risky elements; positioning and repositioning of gymnasts for throws. It was found that in group exercises with 10 clubs all teams started their compositions with elements of cooperation. It should be noted that gymnasts of these teams are the best in the world. Actually we registered model indicators of structural elements. Analysis of researches' results showed that structural elements of space-time indicators of competition compositions are realized effectively in the following cases: high static-dynamic body balance; temp and rhythm of movements; flexibility; jumping; orientation in space, body balance in difficult rotations and rotations on one foot; motor interaction in system "gymnast-object". Materials of monograph [2] can serve as proof of these, as well as theoretical analysis and practical experience of specialists in sports gymnastics $[1,3,7,8,12$, and 15]. Gymnasts' active participation in composing of competition compositions brings elements of individuality in their content. In motor composition these elements become a "face" of all composition. They characterize performance skillfulness and are a mean of creation of artistic image [6, 7, and 11]. Analysis of scientific-methodic literature, devoted to effective building of individual and group exercises' competition compositions, witnesses about importance of this problem. The known specialists point at the fact, that composition is an artwork, free for creativity [14]. Restrictions are imposed only by competition rules. They concern time, sixes of platform and quantity of elements, determining value of all competition exercise. 


\section{Conclusions:}

1. Analysis of scientific-methodic literature and practical experience of coaches permitted to mark out the most important components of the process as well as to accentuate ability of coaches and female gymnasts to consider spacetime structural elements of exercises and fulfill them technically accurately.

2. Time indicators permit to asses the following: level of female gymnast's fitness; her ability to fulfill elements of competition compositions in individual exercises. Quickness of preparation to elements' fulfillment and directly time of their fulfillment are of great importance. In calisthenics sportswoman's ability to distribute movement on platform's area is also of great importance, as well as change of directions. For example, abrupt and jerky music is in harmony with change of directions under acute angles; soft music - corresponds to obtuse angles or to arch-like pictures of motion. To create impression of quickness and lightness direction from the left to the right is chosen. In this case spectator's look will as though "prod" the movement. When moving to other side it is more advantageous to use direction from the right to the left. Thus, correct and logical distribution of elements and combinations on platform; gymnast's movements create artistic completeness of composition.

3. Study of space-time characteristics of group exercises' compositions showed that the most permanent component of structure was cooperation and interaction. It is a basic normative foundation of compositions' building. Cooperation elements take $70-80^{\prime \prime}$. It is $45-55 \%$ of total exercise's duration. Cooperation elements bring $40-45 \%$ of total basic mark for composition. That is why it is purposeful to fulfill different kinds of interactions, which can be supported by criteria of different complexity: for example, cooperation, when gymnast does not control object, or without help of hands. Kinds of supports and gymnasts' passing under or above object also are included in it. The research of content of modern group exercises' competition compositions permitted to find that important condition of their quality is logical character, variety and correspondence of positioning and re-positioning to gymnasts' fitness level

\section{Acknowledgements:}

The researches have been fulfilled in compliance with combined plan of SRW in sphere of physical culture and sports for 2011-2015 by topic 2.15 "Control of body and system of bodies static-dynamic balance in kinds of sports with complex coordination of movements' structure" (state registration number 0111U001726). Scientific supervisor of the topic - doctor of pedagogic science, Professor V.N. Boloban.

\section{Conflict of interests}

The authors declare that there is no conflict of interests.

\section{References:}

1. Averkovich EP. Kompoziciia uprazhnenij v khudozhestvennoj gimnastike [Composition of exercises in calisthenics], Moscow: USRIPC; 1989. (in Russian)

2. Boloban VN Reguliaciia pozy tela sportsmena [Regulation of sportsman' body posture], Olympic Literature; 2013. (in Russian)

3. Viner IA. Artistichnost' i puti ee formirovaniia [Artistry and ways of its formation], Moscow: Human; 2014. (in Russian)

4. Denisova LV, Usichenko VV, Bishevec' NG. Analiz anketnikh danikh v sportivno-pedagogichnikh doslidzhenniakh [Analysis of questioning in sports-pedagogic researches], Pedagogics, psychology, medical-biological problems of physical training and sports, 2012; 1: 56-60 (in Ukrainian)

5. Karpenko LA. Komponenty sportivnogo $i$ ispolnitel'nogo masterstva $v$ gimnastike [Components of sports and performance skillfulness in gymnastics]. Nauchno-prakticheskaia konferenciia, posviashchennaia 100-letiiu so dnia rozhdeniia L.P. Orlova [Scientific-practical conference, devoted to 100 anniversary from birth of L.P. Orlov], Sankt Petersburg; 2001. P. 69-73 (in Russian)

6. Karpenko LA. Khudozhestvennaia gimnastika [Calisthenics], Moscow: Federation of Russia; 2003. (in Russian)

7. Miroshnichenko T. Metodika postanovki suchasnikh kompozicij grupovikh vprav u khudozhnij gimnastici [Methodic of composing of group exercises' compositions in calisthenics]. Teoriia i metodika fizichnogo vikhovannia i sportu, 2001; 4: 11-13 (in Ukrainian)

8. Morozevich-Shiliuk T. Artistizm akrobatov vysokogo klassa [Artistry of elite acrobats]. Nauka volimpijskom sporte, 2012;1: 74-80 (in Russian)

9. Nachinskaia SV. Matematicheskaia statistika v sporte [Mathematical statistic in sports], Kiev: Health; 1987. (in Russian) 
10. Nesterova TV, Bogorad OA. Sredstva vyrazitel'nosti sportivno-khudozhestvennykh kompozicij v khudozhestvennoj gimnastike [Means of expressiveness of sport-art compositions in calisthenics]. Fizicheskoe vospitanie studentov tvorcheskikh special'nostej, 2005; 5: 24-31. (in Russian)

11. Omel'ianchik O, Saliamin Iu, Dobrovol'skij E. Sravnitel'nyj analiz sorevnovatel'noj deiatel'nosti ukraiskikh gimnastov v olimpijskom cikle 2009 - 2012 godov [Comparative analysis of competition functioning of Ukrainian gymnasts in Olympic cycle 2009 - 2012]. Nauka v olimpijskom sporte, 2012; 1: 81-83. (in Russian)

12. Omel'ianchik-Ziurkalova OA. Model'noe postroenie kompozicij na vol'nykh uprazhneniiakh $\mathrm{s}$ uchetom khoreograficheskoj podgotovlennosti gimnastok [Simulation of compositions with free exercises, considering choreographic fitness of female gymnasts]. Nauka $v$ olimpijskom sporte, 2015; 1: 63-67. (in Russian)

13. Sosina VIu. Khoreografiia v gimnastike [Choreography in gymnastics], Kiev: Olympic Literature; 2009. (in Russian)

14. Terekhina RN, Kriuchek ES, Medvedeva EN, Zenovka IB. Sovremennyj podkhod k processu postanovki sorevnovatel'nykh kompozicij $\mathrm{v}$ khudozhestvennoj gimnastike [Modern approach to composing of competition compositions in calisthenics]. Uchenye zapiski, 2014;8:180-185. (in Russian)

15. Tereshchenko IA, Otsupok AP, Krupenya SV, Liauchuk TM, Boloban VN. Coordination training of sportsmen, specializing in sport kinds of gymnastic. Physical Education of Students, 2015;3:52-65. http://dx.doi.org/10.15561/20755279.2015.0307

16. Boloban WN. Reaction time and motor time in an athlete's movements. Pedagogics, psychology, medical-biological problems of physical training and sports, 2009;10:295-301. (in Russian)

17. Zhulkevskaya GV. Gymnastics. Minsk: BGUFK; 2005.

18. Potop V, Grigore W, Marinesku S. Motor learning gymnastic exercises on the basic of transfer technologies. Science in the Olympic sports, 2012;1:47-57.

19. Rules rhythmic gymnastics. Federation international de gymnastique. Losana; 2012.

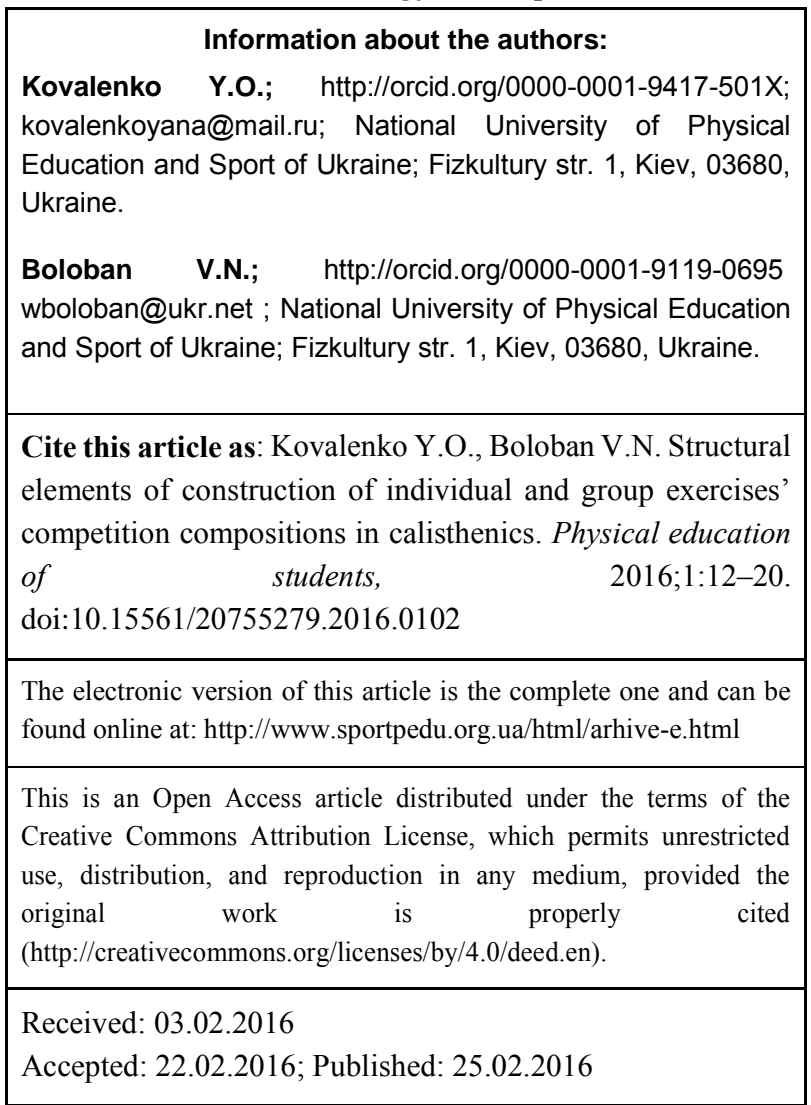

